\title{
Students' intention to take online courses in high school: A structural equation model of causality and determinants
}

\author{
Masood Badri • Asma Al Rashedi • Guang Yang • \\ Jihad Mohaidat • Arif Al Hammadi
}

Published online: 15 June 2014

C The Author(s) 2014. This article is published with open access at Springerlink.com

\begin{abstract}
Offering an online integrated high-school course or subject for the first time involves many challenges. Better understanding the factors that affect students' willingness to participate in the experience could provide support for better implementation of such a strategic initiative. In addition, it is important to understand how personal factors can influence the success of such an endeavour. This study develops a comprehensive structural equation model that captures most causal factors related to offering a high-school course online for the first time. A sample of public and private secondary school students (Grades 10, 11 and 12) in Abu Dhabi were administered an online survey regarding offering free online courses. The instrument was reviewed by other experts in curriculum, information technology and teaching and learning. The final instrument contained dimensions related to student perception of ease of use of elearning, usefulness, self-efficacy, skills, style, student self-reported performance in certain subjects, use of social media, school support, teacher support, general support, access to the internet, and preferences behavioural intentions to use e-learning. The analysis provides a structural equation model with acceptable statistical fits and with
\end{abstract}

M. Badri $(\bowtie) \cdot$ A. Al Rashedi $\cdot$ G. Yang $\cdot$ J. Mohaidat

Abu Dhabi Education Council, Abu Dhabi, United Arab Emirates

e-mail: masood.badri@adec.ac.ae
A. Al Rashedi
e-mail: asma.alrashedi@adec.ac.ae
G. Yang
e-mail: guang.yang@adec.ac.ae
J. Mohaidat
e-mail: Jihad.mohaidat@adec.ac.ae
A. Al Hammadi
Abu Dhabi Education Council, Khalifa University of Science and Technology,
Abu Dhabi, United Arab Emirates
e-mail: Arif.hammadi@adec.ac.ae 
many significant causal relationships. The paths representing direct and indirect effects of the construct predictors on intention to use provided statistical evidence of the validity of the 13 component predictors. Results show significant links between intention to use e-learning, perception of easiness, perception of usefulness, and other factors such as user characteristics and support. Use of social network affect intention to use e-learning indirectly thorough other variables. Limitations and implications of the study in general and as it concerns Abu Dhabi are highlighted.

Keywords E-learning · Self-perception · Self-efficacy · Ease of use · Usefulness · Learning Style $\cdot$ Study habits $\cdot$ Learning preferences $\cdot$ Intention to use and Abu Dhabi

\section{Introduction}

The Abu Dhabi Education Council (ADEC) has initiated curricular and instructional reforms at all levels of its schools. The reformed curriculum aims to equip students with knowledge and skills for developing lifelong learning capabilities. One of the core objectives is to help students to use current technology. Since 2008 the ADEC has dictated that information technology (IT) and related courses be incorporated into all levels of schooling. In 2013 the ADEC embarked on a full-scale project to design a variety of online courses for both public and private highschool students, with the development of online initiatives for other age groups in the second phase. It is believed, in order for online learning to be successful, all aspects of students' acceptance of such an endeavour must be carefully studied and understood.

Many researchers have studied the use of information technology in education, seeking to identify the factors that influence the likelihood of successful implementation of innovative technologies in an educational setting (e.g. Surjono 2014; Mahdizadeh et al., 2008; Brett and Nagra 2005; Cheung \& Huang, 2005; Dewiyanti et al., 2007). E-learning can be viewed as the delivery of course content via electronic media, such as the Internet, intranets, extranets, satellite broadcasts, audiotapes, videotapes, interactive television and CD-ROMs (Selim, 2007). E-learning has also been referred to as Web-based learning, Internet-based training, advanced distributed learning, Web-based instruction, online learning and open/Xexible learning (Khan, 2001, Kiili, 2005). E-learning encompasses asynchronous or self-paced learning. It refers to the use of Internet technologies to deliver a broad array of solutions that enhance knowledge and performance (Yang and Wang, 2014; Rosenberg, 2001). Compared to face-to-face teaching, some research has shown that students were more satisfied with their learning experiences when taking an online course (Yang and Wang, 2014). Wang (2003) noted that e-learning can fortify student participation and interaction, give students a more active role in their learning, provide increased motivation and make them more independent in the educational process.

Research has shown that e-learning has many advantages and benefits related to providing time and place flexibility; resulting in cost and time savings for educational institutions; fostering self-directed and self-paced learning by enabling learner-centred activities; creating a collaborative learning environment by linking each learner with physically dispersed experts and peers; and allowing knowledge to be maintained and 
updated in a more timely and efficient manner (Adewole-Odeshi 2014; Shen \& Chuang, 2010; Pituch \& Lee, 2006).

More specifically, offering online subjects to high-school students in Abu Dhabi has several positive features both economically and academically:

- The remote geographic location of some schools prevents them from attracting the best teachers for certain subjects. To attract better teachers, extra remote-area allowances must be paid.

- The rate of teacher absences in some schools leaves many students without teachers (or substitute teachers).

- Some schools have no competent teachers at all in certain subjects.

- Variations in teacher competence (based on student perception) are very high.

Research on student acceptance of distance learning or online studies point out the importance of carefully studying and analysing the factors of student motivation, attitudes toward learning, attitudes toward technology, selfconfidence, anxiety, beliefs and values (Bender et al., 2004; Conrad, 2002). This study examines the perceptions of secondary-school students regarding the factors that contribute to the success of online instruction and their intention to use this mode of learning.

\section{Objectives of the study}

Most previous studies focused on the use or acceptance of e-learning in higher education (Back et al., 2014; Arbaugh, 2000; Peng et al., 2006). Only a few studies have looked at e-learning readiness or intentions to use in e-learning high schools or elementary schools (Horzum \& Cakir 2012). To contribute to the development of effective online learning at the high-school level, this study will examine dimensions of online learning as perceived by students in public and private high schools in Abu Dhabi.

The objective of this research is to scrutinize expected e-learners' intentions to offer e-learning programs efficiently and effectively. Results will provide better understanding about learners' attitudes towards e-learning and their intention to take online courses in Abu Dhabi high schools. This study will develop a suitable model to measure students' intention to use online courses. Measuring attitudes toward elearning and the factors that impact decisions whether to use this mode of instruction should provide better insight about learners' willingness to accept e-learning programs.

This study investigates the causal relations among several constructs that may impact the degree of secondary-school students' intention to use online learning resources and the perceived quality of these resources. The variables were chosen based on extensive review of previous empirical works. Early identification of relevant variables and their relationships with each other could provide the means to increase the likelihood of positive online learning experiences.

Several research questions emerging from the literature review were addressed in this project. These questions move us beyond the comparison of specific course-related experiences (i.e. online versus classroom experiences) to a more 
holistic and system-wide view of learning experiences. These questions are framed around a central issue related to perceived quality of online learning experiences.

\section{Literature review}

The growth of the Internet and the ensuing transformation of the educational landscape have led to the adoption of a variety of Web-based tools, giving rise to the trend of elearning in education (Liao \& Lu, 2008). The increasing availability of wireless and mobile technology makes e-learning more ubiquitous and pervasive (Petrova, 2007). Elearning technology opens up possibilities for new ways of engagement and invites innovative pedagogies (Yuen \& Ma, 2008). This phenomenon has caused many changes in the education arena. The digital mindset has created new challenges for both students and teachers in terms of their ability to cope with technology (Smith \& Hardaker, 2000).

E-learning uses network technologies to create, promote, deliver and facilitate learning with no time and place constraint. The flexibility of e-learning can take different forms, including self-directed pace (McVeigh, 2008), just-in-time learning (Liaw \& Huang 2003; Rosenberg, 2001; Jonsson, 2005) and flexibility of format.

Bouhnik and Marcus (2006) note that e-learning programs face many challenges that include, lack of a framework encouraging students to learn, the need for a high level of self-discipline, the lack of a learning atmosphere, the minimal level of contact and discussion among students, the lack of interpersonal and direct interaction among students and teachers and the less efficient learning process in comparison to the face-to-face learning method as students generally must dedicate more time to learning the subject matter. However, students can obtain an intimate learning experience and have effective interaction with their instructors without attending a brick-and-mortar facility (El-Deghaidy \& Nouby, 2008; Liao \& Lu, 2008; Sun and Tsai 2008; Wu and Tennyson 2008).

ost education-related research on factors of success in or intention to use e-learning has concentrated on higher education. Critical factors in e-learning include technology (ease of access and navigation, interface design and level of interaction); the instructor (attitude toward students, technical competence and classroom interaction); and the students' previous use of technology (Volery \& Lord, 2000). Soong et al. (2001) stressed human factors, technical competence of both instructor and student, elearning mindset of both instructor and student, level of collaboration and perceived information technology infrastructure. Helmi (2002) focused on technology, instructor characteristics and student characteristics. Govindasamy (2002) noted the importance of institutional support, course development, teaching and learning, course structure, student support, faculty support and evaluation and assessment. Baylor and Ritchie (2002) explored the impact of independent factors related to educational technology (planning, leadership, curriculum alignment, professional development, technology use, instructor openness to change and instructor computer use outside school) on five dependent measures (instructor's technology competence, instructor's technology integration, instructor morale, impact on student content acquisition and higher-order thinking skills acquisition) using stepwise regression. 
Many research studies have addressed factors influencing the adoption of elearning. Piccoli et al. (2001) noted factors such as maturity, motivation, technology comfort, technology attitudes, computer anxiety, epistemic beliefs, technology control, technology attitudes, teaching styles, self-efficacy, availability, objectivist and constructivist, quality, reliability, pace, sequence, control, factual knowledge, procedural knowledge, conceptual knowledge, timing and frequency. Stokes (2001) focused on students' temperaments (guardian, idealist, artisan and rational). Arbaugh (2002) noted perceived flexibility of the medium, perceived usefulness and ease of use, media variety, prior instructor experience, virtual immediacy behaviours, and interaction. Arbaugh and Duray (2002) highlighted perceived usefulness, ease of use and flexibility. Hong (2002) noted the importance of gender, age, scholastic aptitude, learning style, initial computer skills, interaction with instructor, interaction with fellow students, course activities, discussion sessions and time spent on the course. Thurmond et al. (2002) stressed the importance of computer skills, courses taken, and initial knowledge about elearning technology, age, receiving comments in a timely manner, offering various assessment methods, available time to study, scheduled discussions, teamwork and acquaintance with the instructors. Kanuka and Nocente (2003) listed factors such as motivating aims, cognitive modes and interpersonal behaviours learner dimension, learner attitude toward computers, learner computer anxiety, learner Internet self-efficacy Instructor dimension, instructor response timeliness, instructor attitude toward e-Learning, design dimension, perceived usefulness, and perceived ease of use.

Several factors have received extensive attention and research related to e-how users feel about learning: expectations, usefulness, and intention to use. The following is a list of most recognized determinants.

- Learner's knowhow and comfort with IT, previous experience and self-efficacy (Cheurprakobkit et al., 2002; Peng, Tsai \& Wu, 2006; Tsai \& Lin, 2004; Liaw et al., 2007; Joo et al., 2000; Thompson et al., 2002; Wang and Newlin, 2002; Beyth-Marom et al., 2003; Papp, 2000; Piccoli et al., 2001; Barbeite \& Weiss, 2004).

- Perceived usefulness and perceived ease of use (Davis, 1989; Arbaugh, 2000; Arbaugh, 2002; Wu and Tennyson 2008; Arbaugh \& Duray, 2002; Arbaugh, 2002; Pituch \& Lee, 2006; Piccoli et al., 2001; Lee \& Lee, 2008; Chiu et al., 2005; Roca and Chiu 2006).

- Learners' learning style, study habits and learning preferences (Hu et al., 2007; Rong \& Min, 2005; Gomes et al. 2007; Manochehr 2006; Graf and Kinshuk, 2006; Carmo et al. 2006, September; Liaw; 2004; Passerini and Granger, 2000; Liaw 2007; Vuorela \& Nummenmaa 2004a; Liaw \& Huang 2007; Lim and Lee 2007; Liaw et al., 2007; Lee and Lee, 2008; Latchem et al., Liaw 2007; Liaw \& Huang 2007; Lim and Lee 2007; Wang 2008).

- Support and feedback from teachers, other students, family and community (Thurmond et al., 2002; Arbaugh, 2000; Piccoli et al., 2001; Moore, 1989; Alexander et al., 1998; Soong et al., 2001; Surry et al., 2005; Hara, 2000).

- IT and infrastructure characteristics and support (Ruth, 2006; Pituch \& Lee, 2006). 
- Teacher attitude and competence related to IT (Kim et al., 2010; Albirini, 2006; Breen et al., 2001; Marriott et al., 2004; Selim, 2007; Albirini, 2006; Cheung and Huang, 2005; Arbaugh, 2002; Thurmond et al., 2002; Soon et al., 2000; Piccoli et al., 2001; Liaw 2007; Wang 2008 Liaw 2007; Arbaugh, 2002; Arbaugh \& Duray, 2002; Hong, 2002; Piccoli et al., 2001; Liaw and Huang, 2003; Liaw et al.; 2007; Liaw, 2007; Vuorela and Nummenmaa, 2004b; Collis et al., 2001; Ong \& Lai, 2006 [In the current study, however, we focused on students' intention to use a wide variety of e-learning environment functions and their opinions about the added value of these features for learning processes].

- Student characteristics (Thurmond et al., 2002; Arbaugh, 2000; Keller and Cernerud, 2002; Selwyn, 2007; Stansfield et al., 2004; Hung et al., 2010).

- Experience with using social networking (Antal 2007; Mason 2006; Silius et al., 2010; Rosen and Nelson, 2008; Ullrich et al., 2010).

- Students' school outcomes or performance (Oye et al. 2012; Holley, 2002; McGill et al. 2009; Lee and Lee, 2008; Erdogan et al., 2008).

Toward an integrated framework of intention to use e-learning in high school

There are few models that deal with intention to use e-learning among high-school students. In addition, with the advancement of technology and the changes in technological resources, there is a need to integrate the new resources into these models to see if they contribute in any way toward encouraging high-school students to use the online courses offered to them.

\section{Methods and design}

\subsection{Survey instrument}

A survey instrument on intention to use online courses and factors related to this intention was developed, using the research literature on e-learning. The survey instrument consisted of several sections. The first section asked for students' gender, class grade, type of school and school location. The next section asked the students to state how often they used certain social media resources. Five answer choices were offered, from 'never' to 'very frequently'. The choices of social media resources included YouTube, Facebook, Instagram, Keek and Twitter. The third section asked the students to specify their level of comfort in performing IT-related activities such as keyboarding, accessing and using the Internet, using search engines, sending and receiving documents electronically, downloading documents, downloading multimedia materials, listening to audio on the computer and viewing video on the computer. For these questions, the five response options ranged from 'novice' to 'expert'. The fourth section asked about student performance in math, science, English, IT and social subjects, with answer choices from 'poor' to 'excellent'.

The subsequent sections contained sets of items that were grouped together. The groupings were related to e-learning self-efficacy; expectations about the ease of use of an e-learning system; expectations about the usefulness of e-learning' the 
student's learning style, study habits and learning preferences; behavioural intentions toward e-learning; perceptions of level of access at home; expectations about the availability of technical support in school; perceptions of the capability of teachers in the school to deal with e-learning; and peer encouragement and support. Scoring choices ranged from 'completely disagree' to 'completely agree'.

\subsection{Study sample}

High-school students, or cycle 3 students, from Abu Dhabi were selected to participate in the study. They were attending grades 10, 11 and 12. This cycle was selected because the first phase of the e-learning project would serve only students from this cycle. Currently most of the students in this cycle use only traditional learning tools. However, some students in certain schools have limited experience with laptop-based courses. Traditional learning tools used in the selected courses are required attendance, regular textbooks and presence of the instructor during the scheduled class time.

Some private-school students in Abu Dhabi have introduced e-learning tools such as electronic student-to-student and student-instructor communication, asynchronous course material delivered through a Blackboard (course management information system) course website, in-class active and collaborative learning activities and student self-pacing patterns.

The survey instrument was posted on the ADEC website from October 6 to November 3, 2013. A letter from the ADEC Director General in ADEC went to every cycle 3 school principal in Abu Dhabi, requesting their cooperation. The letter contained the link where students could go to complete the survey, which required approximately $10 \mathrm{~min}$.

\subsection{Structural equation model}

Several measurement models are used in this study. Before full structural equation analysis is carried out, a test of each measurement model is required. The tests are intended to identify the significant items in each measurement model to use in further analysis. The measurement models are related to several constructs in the study. The constructs in the model include:

- Self-perception of level of comfort with IT and the Internet (8 items)

- E-learning self-efficacy (4 items)

- Expectations about the ease of use of e-learning (3 items)

- Expectations about the usefulness of e-learning (8 items)

- Learners' learning style, study habits and learning preferences (7 items)

- Behavioural intentions toward e-learning (7 items)

- Perception of level of access at home (3 items)

- Expectations about the availability of technical support at the school (2 items)

- Perception of teacher competence in e-learning (3 items)

- Peer encouragement and support (4 items)

- Self-reported school performance (5 items)

- Frequency of using social network resources (4 items) 
For those constructs with more than three items, a full confirmatory factor analysis was be applied and fit statistics were checked. LISREL output was used to suggest which indicators should be retained and which ones should be separated from other indicators to form other factors (or constructs).

Structural equation modelling (SEM) techniques have been used widely in measuring user acceptance of information technology (Venkatesh et al. 2003; Chwelos, Benbasat \& Dexter, 2001; Koufaris, 2002; Lederer, Maupin, Sena \& Zhuang, 2000; Rai, Lang \& Welker, 2002; Rai, Venkatesh et al. 2003; Venkatesh \& Davis, 2000). The general SEM model for this study is shown in Fig. 1. The four main components are user characteristics, ease of the system, usefulness of the system and intention to use the e-learning system.

The validity of the model was assessed by LISREL, which generates various measures in order to evaluate the goodness of fit of the research model. The most popular index is perhaps the chi-square statistic, which tests the proposed model against the general alternative in which all observed variables are correlated (in LISREL terms, unconstrained). With this index, significant values indicate poor model fit while insignificant values indicate good fit. Other measures of fit include degrees of freedom, Non-Normed Fit Index (NNFI), Comparative Fit Index (CFI), Average Absolute Standardized Residual (AASR), Goodness-of-Fit Index (GFI), Adjusted Goodness-of-Fit Index (AGFI) and Root Mean Square Residual. There are many writings on the acceptance threshold with regard to each fit statistic. Poor goodness of model fit indicates possible model misspecifications. Two parts of the LISREL output, standardized residuals and modification indices, can be used to help in determining possible sources of the lack of fit. Generally, LISREL consists of two distinct parts: the confirmatory factor model and the structural equation model (Segars \& Grover, 1993). The confirmatory factor model specifies the relations of the observed factors to their posited underlying constructs. The structural equation model specifies the relationships of the constructs to one another as posited by research models.

Since missing values were random and not significant (only $0.16 \%$ of the cases), all cases with missing values were omitted from further analysis. To assess reliability, Cronbach's alpha was recorded for all constructs. For those constructs with a larger

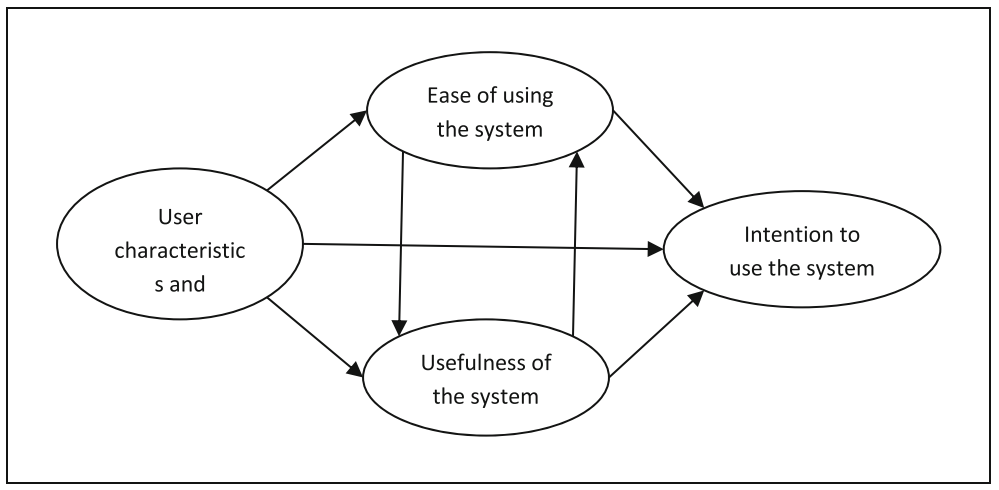

Fig 1 General SEM model of user intention to use the e-learning system 
number of items, a full confirmatory factor analysis was applied and fit statistics were checked. Standardized factor loadings or standardized validity coefficients were calculated. LISREL output suggested which indicators should be retained and which ones should be separated from other indicators to form other factors (or constructs).

A cross validation of the structural equation model was necessary to test the ability of the model to be invariant across two or more random samples from the same population. The two samples used were students from public schools and students from private schools in Abu Dhabi. This null hypothesis states that the measurement model parameters (factor loadings, factor variances, factor covariances and measurement error variances) are identical (invariant) across the two samples. The alternative hypothesis states that at least two parameters of the measurement model are not identical across the two samples. A Chi-square difference test is used to assess the cross validation of the measurement model.

\subsection{The study hypotheses}

As suggested by Fig. 1, several main hypotheses must be tested, all of which are related to the causal effects between the main constructs of user characteristics and support, ease of use, usefulness of system and intention to use the system:

- $\mathrm{H}_{1}$ : Causal relationship between user characteristics/support and perception of system easiness.

- $\mathrm{H}_{2}$ : Causal relationship between user characteristics/support and perception of system usefulness.

- $\mathrm{H}_{3}$ : Causal relationship between user characteristics/support and perception of intention to use the system.

- $\mathrm{H}_{4}$ : Causal relationship between perception of system easiness and system usefulness.

- $\mathrm{H}_{5}$ : Causal relationship between perception of system easiness and intention to use the system.

- $\mathrm{H}_{6}$ : Causal relationship between perception of system usefulness and intention to use the system.

The elements of user characteristics include user skills, user efficacy and user style. The elements of support include access, support from school and teachers and general support from peers, home and community. Other variables to be added include use of social media and student self-perception of performance in major academic subjects.

\section{Results}

A total of 7,950 students responded to the call (representing a response rate of $13 \%$ of all students in grades 10, 11 and 12 in Abu Dhabi - (53\% males and 46\% females). The sample was slightly skewed toward younger students $(40.5 \%$ in grade $10,35.1 \%$ in grade $11,24.5 \%$ in grade 12 ). About $43.6 \%$ of the students were from public schools. Students from the Abu Dhabi region constituted 50\% of the sample, with $38.9 \%$ coming from the Al Ain region and 11.1\% from Gharbia. All students participated 
voluntarily in the study. Tables $1 \mathrm{~A}$ and $1 \mathrm{~B}$ show the constructs, along with the mean scores and standard deviations of the final items used in each construct.

Descriptive statistics of the items from the surveys are also provided in Tables 1A and 1B. All items used a scale ranging from 1 (do not agree at all) to 5 (highly agree). With regard to social media, YouTube was the most used resource while Keek is the least used. The sample of students was characterized by relatively high skills in using computer-based technology resources. The students also indicated high performance in core school subjects, with social studies grades averaging the highest. Both school support and teacher support received high scores, while community support was the highest of all. Almost all students enjoyed high levels of Internet access at home. The highest student efficacy was related to 'having the technological knowledge and skills necessary to use e-learning' while the lowest efficacy was related to 'I am among the first in my circle of friends to acquire new technology'. Relatively high scores were assigned to expectations regarding ease of use of the e-learning system. Students also expected the e-learning system to be useful. The highest score was given to 'e-learning will help me improve the quality of my projects'. Students also indicated that they were 'open to new ideas' and they considered face-to-face interaction with their instructors and fellow students to be highly important. Overall, the results showed that students expressed positive intentions about using the e-learning system.

\subsection{Prior analysis and results}

When descriptive statistics were computed for each of the 12 constructs, observation found most of them to be negatively skewed and kurtotic; that is, the standardized skewness values were not within the range expected for data from a normal distribution. Several features were analysed further. These features included the constructs' measures of central tendency, variability and shape. Of particular interest here were the standardized skewness and standardized kurtosis, from which we could determine whether the sample represented a normal distribution. Values of these statistics outside the range of -2 to +2 would indicate significant departures from normality, which would invalidate many of the statistical procedures normally applied to these data. The data exhibited standardized skewness values outside the expected range for all variables. Table 2 presents the correlation coefficients among the constructs used in this study. Most bivariate correlations were relatively high and significant. We found the highest correlations between 'ease of use' and 'usefulness' (0.783) and between 'usefulness' and 'intention to use' (0.718).

To create more normally distributed scores, we subjected the variables to rank transformations and then converted these to z-scores. These transformed values were used in all subsequent analyses. Tables $1 \mathrm{~A}$ and $1 \mathrm{~B}$ also contain the original means and standard deviations of each of the constructs. The 12 constructs were relatively high with regard to their internal consistencies (Cronbach reliability coefficients were all above the minimum .070 threshold). However, the construct related to using social media had a relatively low reliability (0.651). As a result, it was split into two constructs, Media 1 (Instagram, Keek and Twitter) and Media 2 (Facebook and YouTube). Hence, 13 constructs resulted. 
Table 1A Descriptive scores for survey items (user and supports)

Social media (Using certain social media resources) [2.968, 1.0264]

Mean S.D.

Med1 YouTube

$3.86 \quad 1.025$

Med2 Facebook

$2.94 \quad 1.008$

Med3 Instagram

$2.91 \quad 1.077$

Med4 Keek

$2.15 \quad 1.007$

Med5 Twitter

$2.98 \quad 1.015$

Skills (Using certain computer-based technology activities) [3.923, 1.1095]

Mean S.D.

Skill1 Typing, keyboarding

$3.72 \quad 1.138$

Skill2 Accessing and using the Internet

$4.24 \quad 0.958$

Skill3 Using search engines (e.g. Google, Yahoo)

$4.27 \quad 1.005$

Skill4 Sending and receiving documents electronically

$3.66 \quad 1.187$

Skill5 Downloading documents

$3.69 \quad 1.102$

Skill6 Downloading multimedia materials

$3.73 \quad 1.164$

Skill7 Listening to audio on the computer

$4.05 \quad 1.192$

Skills Viewing video on the computer

$4.02 \quad 1.130$

Performance (Self-reported performance in certain subjects) [3.729, 1.1122]

Mean S.D.

Perf1 Math

$3.58 \quad 1.174$

Perf2 Science or related subjects

$3.63 \quad 1.067$

Perf3 English

$3.65 \quad 1.145$

Perf4 Information technology (IT)

$3.78 \quad 1.128$

Perf5 Other social subjects

$3.98 \quad 1.047$

School support [3.555, 1.139]

Mean S.D.

SchS1 The school has IT technical support person (s) whom I can turn to if I face technical problems

SchS2 The students in my class have good knowledge and skills to provide technical support

Teacher support [3.543, 1.167]

Mean S.D.

Tech1 The teachers at school are capable of handling online subjects

$3.51 \quad 1.188$ if asked to do so

Tech2 The teachers at school are competent IT users $\quad 3.50 \quad 1.155$

Tecg3 The teachers at this school have a positive attitude toward IT $\quad 3.62 \quad 1.160$

Other support $[3.86,1.158]$

Mean S.D.

OthS1 My classmates will strongly support the practice of offering some online classes

3.91

1.145

OthS2 My teachers will strongly support the practice of offering some online classes

$3.66 \quad 1.180$

OthS3 My family will strongly support the practice of offering some online classes

$3.84 \quad 1.181$

OthS4 The community will strongly support the practice of offering some online classes

Home access [4.157, 1.045]

Mean S.D.

HAcc1 I have a high-speed connection to the Internet at home

$4.10 \quad 1.070$

HAcc2 I have convenient access to the Internet at home

$4.19 \quad 1.031$

HAcc3 I have easy access to the technology to make Internet surfing fast and

$4.18 \quad 1.033$ easy at home 
Table 1B Descriptive scores for survey items (other constructs)

Self-efficacy $[3.675,1.082]$

Mean S.D

Effic1 Other people come to me for advice on new IT technologies

$3.47 \quad 1.075$

Effic2 I usually figure out new high-tech products and services without help from others

$3.70 \quad 1.074$

Effic3 I am among the first in my circle of friends to acquire new technology

3.391 .136

Effic4 I have the technological knowledge and skills necessary to use e-learning

$3.84 \quad 1.041$

Easiness of the system [3.997, 1.031]

Easy1 I expect to find an e-learning system clear and understandable for me

Mean S.D.

Easy2 I expect that it will be easy for me to become skillful at using

$3.94 \quad 1.078$ an e-learning system

Easy3 I expect that I will find an e-learning system easy to use $\quad 4.03 \quad 1.009$

Usefulness of the system [3.924, 1.084]

UseF1 E-learning will make it easier for me to learn

Mean S.D.

UseF2 E-learning will help me to accomplish study tasks more quickly

$3.92 \quad 1.087$

UseF3 E-learning will help me to obtain a better grade

$3.98 \quad 1.081$

UseF4 E-learning will help me to gain better control over my studies

$3.81 \quad 1.107$

UseF5 I like e-learning because it is not limited to regular school hours

$3.82 \quad 1.095$

UseF6 E-learning will help me to improve the quality of my projects

$3.90 \quad 1.125$

UseF7 E-learning will enhance the overall effectiveness of my study activities

$4.08 \quad 1.038$

UseF8 For future advanced degrees or certificates, I would probably use e-learning

$3.91 \quad 1.056$

Learning style [3.989, 1.006]

$3.96 \quad 1.091$

Styl1 I am open to new ideas

Mean S.D.

Styl2 I am a motivated and self-directed learner

$4.17 \quad 0.958$

Styl3 I do not quit just because things get difficult

$3.93 \quad 0.984$

Styl4 I usually work on assignments in a place where there are no distractions

$4.01 \quad 0.972$

Styl5 Face-to-face interaction with my instructors and fellow

$3.97 \quad 1.046$

students is very important

Styl6 I like to learn in a group, but I can learn on my own too

$4.10 \quad 1.003$

Styl7 I usually accomplish everything that I set out to do in a day

$4.04 \quad 1.031$

$3.70 \quad 1.052$

Intention to use the system $[3.883,1.070]$

Mean S.D.

Intn1 I intend to be a heavy user of e-learning systems

$3.56 \quad 1.157$

Intn2 I would use e-learning systems to obtain class notes and lecture outlines

$3.88 \quad 1.053$

Intn3 I would use e-learning systems to make contact with the teacher

$3.86 \quad 1.092$

Intn4 I would use e-learning systems to access general class information

$3.97 \quad 1.045$

Intn5 I would use e-learning systems to access class reading material

$3.98 \quad 1.031$

Intn6 I would use e-learning systems to discuss results of assignments

$3.92 \quad 1.061$

Intn7 I would use e-learning systems to get help with studying for

$4.01 \quad 1.055$ assignments and exams

Each of the constructs was represented by a single variable (summed scores of all the items in the same construct). A single summed score was computed to represent the measures. This study used path analysis as a result of these modifications. 


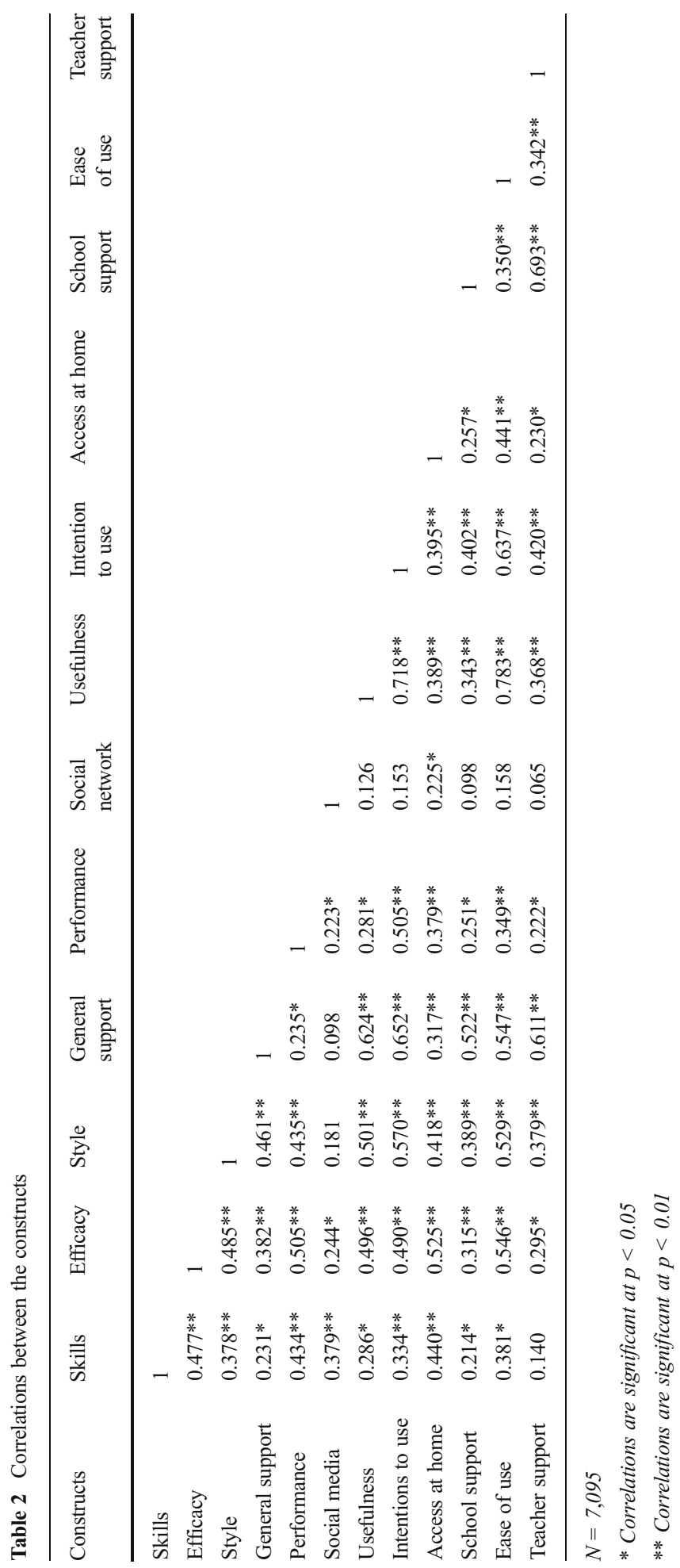




\subsection{Test of the predictive model}

LISREL 9.1 tested the overall fit of the path models. We first ran the general model depicted in Fig. 1, where all constructs are affecting the 'easy to use' construct. In addition, both 'easy to use' and 'usefulness' are affecting the 'intention to use'. The concept portrayed in this model is suggested by other researchers, but with fewer factors influencing 'easy to use'. In addition, most of the previous research involved students in higher education or students already using on-line sources. The analysis did not provide an acceptable model $\left(\chi^{2}\left[20^{\circ}\right.\right.$ of freedom $]=1985, \mathrm{CFI}=0.85, \mathrm{RMSEA}=$ 0.144). The model was also modified to include only the factors cited most often as affecting intention to use. The next model let four constructs (efficacy, access, style and support) influence the construct 'easy to use'. The analysis yielded better but still unacceptable results $\left(\chi^{2}\left[8^{\circ}\right.\right.$ of freedom $\left.]=285, \mathrm{CFI}=0.92, \mathrm{RMSEA}=0.094\right)$ (Tables 3, 4 and 5).

Next, we used LISREL output modification results to identify a model with the most adequate fit. Figure 2 depicts the best-fit model for the data on Abu Dhabi high-school students' intention to use e-learning $(\chi 2[43]=114.84, \mathrm{p}<0.0838, \mathrm{CFI}=0.997$, $\mathrm{RMSEA}=0.053, \mathrm{RMR}=0.0311, \mathrm{SRMR}=0.022, \mathrm{NFI}=0.997, \mathrm{NNFI}=0.992, \mathrm{GFI}=$ 0.991 and AGFI = 0.984). The full model accounted for $84.2 \%$ of the variance in intention to use e-learning.

\subsection{Structural equation model validation}

A cross validation of the structural equation model was necessary to test the ability of the model to be invariant across two or more random samples from the same population. The two samples used were students from public schools and students from private schools in Abu Dhabi. A Chi-square difference test is used to assess the cross validation of the measurement model. The test results in a large p-value (0.11029) which suggests that there is sufficient evidence that the null hypothesis is not rejected. In other words, the cross validation of the measurement model for e-learning is supported by the data of the two samples.

\subsection{Testing hypotheses}

For the best-fit model depicted in Fig. 2, the significant path coefficients were used to test the present study's general hypotheses. All six study hypotheses involve the effect of one or more three general constructs of 'easy to use', 'usefulness' and 'intention to use'. All six hypotheses were supported with significant direct effects or indirect effects.

The first hypothesis involved the relations between user characteristics and support and the ease of using the e-learning system. Many conclusions could be drawn. We note that efficacy directly affects ease of using the system (0.41). However, variables such as Medial and student performance indirectly affect ease of using the system through the variable 'skills'. In addition, Media2 indirectly affects ease of using the system, through self-efficacy. We also note that the general support that the student gets directly affects ease of using the system (0.42). Both efficacy (0.41) and general support (0.42) significantly affect the 'easy to use' construct. Efficacy is strongly 


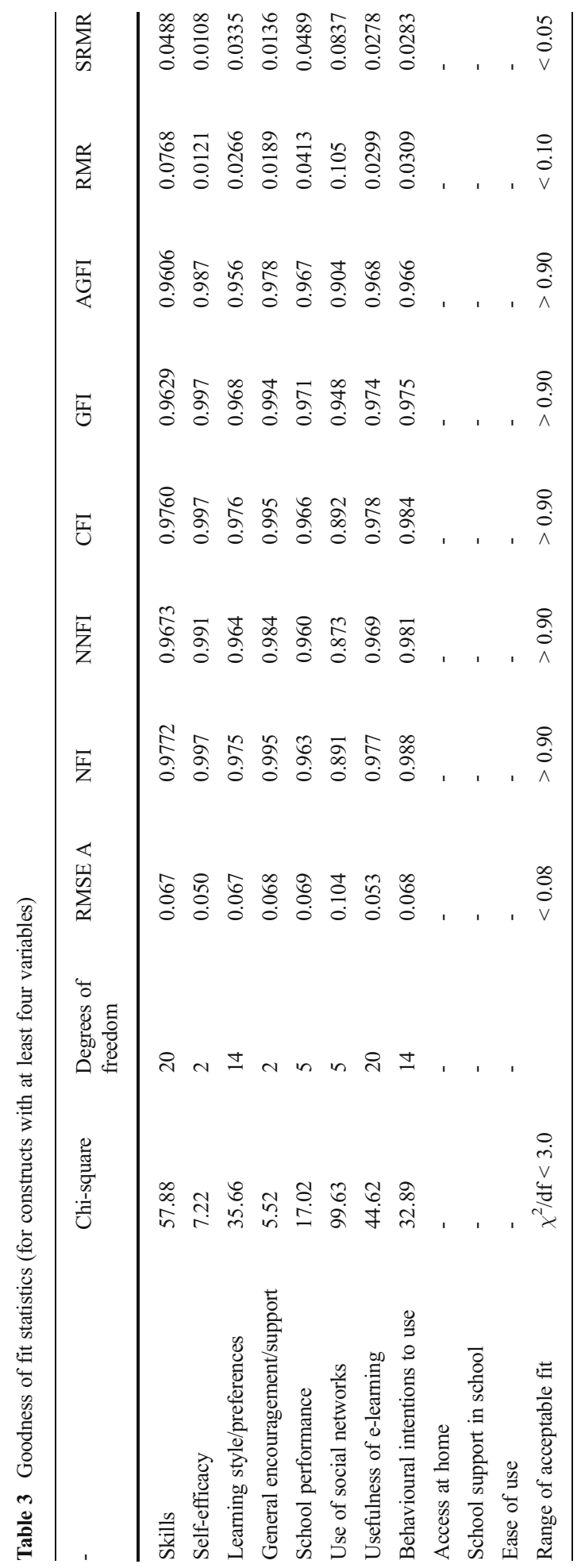


Table 4 Features of constructs used (final SEM modified model)

\begin{tabular}{llllll}
\hline Constructs & $\begin{array}{l}\text { Number } \\
\text { of items }\end{array}$ & $\begin{array}{l}\text { Number } \\
\text { of factors }\end{array}$ & $\begin{array}{l}\text { \% Variance } \\
\text { explained }\end{array}$ & $\begin{array}{l}\text { Cronbach's } \\
\text { Alpha }\end{array}$ & Modifications \\
\hline Social media & 5 & 2 & $70.441 \%$ & 0.651 & $\begin{array}{c}\text { Media was split into 2 factors: Media } \\
\text { 1 (Instagram, Keek and Twitter, } \\
\text { with alpha of 0.736) and Media 2 } \\
\text { (Facebook and YouTube) }\end{array}$ \\
Performance & 5 & 1 & $70.037 \%$ & 0.802 & None \\
Skills & 8 & 1 & $71.78 \%$ & 0.923 & None \\
Self-efficacy & 4 & 1 & $68.84 \%$ & 0.816 & None \\
Access & 3 & 1 & $80.241 \%$ & 0.877 & None \\
Easiness & 3 & 1 & $83.305 \%$ & 0.900 & None \\
General support & 4 & 1 & $72.404 \%$ & 0.873 & None \\
Usefulness & 8 & 1 & $77.839 \%$ & 0.947 & None \\
Style & 7 & 1 & $72.697 \%$ & 0.852 & None \\
Intention to use & 7 & 1 & $70.947 \%$ & 0.931 & None \\
School support & 2 & 1 & $78.044 \%$ & 0.749 & None \\
Teacher support & 3 & 1 & $80.803 \%$ & 0.881 & None \\
\hline & & & & &
\end{tabular}

affected by the user's skills (0.46) and moderately affected by the use of social media such as Facebook and YouTube (0.20). In turn, user skills are significantly influenced by performance in major subjects in school $(0.37)$ and by the use of social media such as Twitter, Instagram and Keek (0.30). Finally, the style of the user is influenced by the degree of support that the school provides $(0.19)$, the degree of support from the teacher

Table 5 Strength of relationships between the constructs in the model

\begin{tabular}{llll}
\hline From & To & Coefficient & Indirect effect on intention to use \\
\hline Easy to use & Usefulness & 0.63 & \\
Easy to use & Intention to use & 0.47 & Intention to use (0.2770) \\
Usefulness & Intention to use & 0.49 & \\
Style of user & Intention to use & 0.48 & \\
General support & Intention to use & 0.30 & Intention to use (0.2440) \\
Skills & Efficacy & 0.46 & Intention to use (0.0523) \\
Media2 & Efficacy & 0.20 & Intention to use (0.0273) \\
General support & Easy to use & 0.42 & \\
General support & Usefulness & 0.29 & Intention to use (0.1584) \\
Access & Style of user & 0.33 & Intention to use (0.0912) \\
School support & Style of user & 0.19 & Intention to use (0.0816) \\
Teacher support & Style of user & 0.17 & Intention to use (0.0157) \\
Media1 & Skills & 0.30 & 0.37 \\
Performance & Skills & &
\end{tabular}




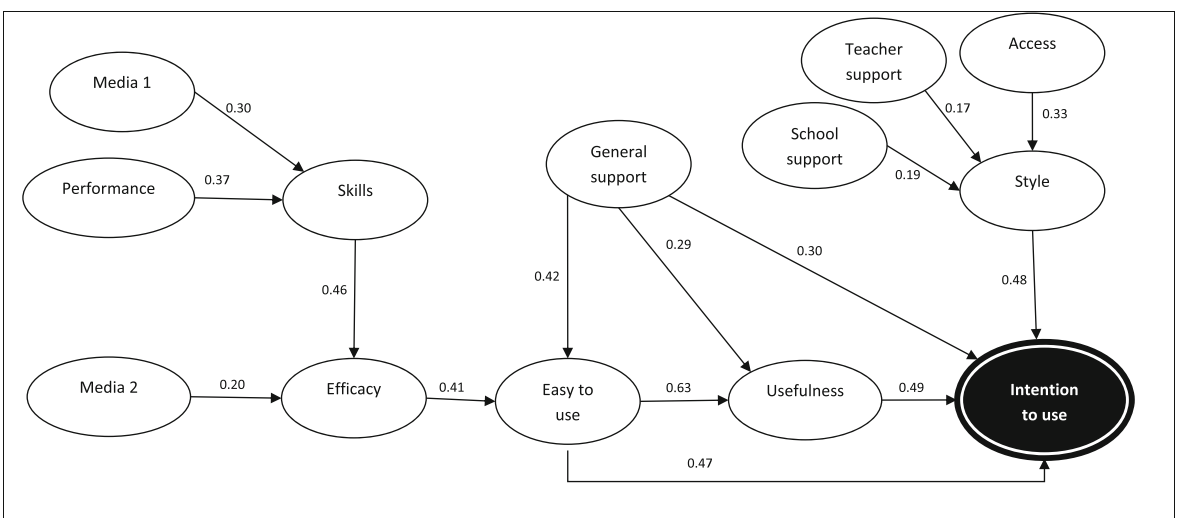

Fig 2 General SEM for intention to use online courses

(0.17) and access at home (0.33). Results also show that some user features (such as user efficacy) and external factors (such as Media2) have a positive impact on whether the user perceives the system as being easy to use.

The second hypothesis is related to the direct or indirect effects of user characteristics and support on the perception of how useful the system is. Results show an indirect effect of user characteristics, through how easy the system is perceived by students. General support directly affects the perception of system usefulness (0.29).

The third hypothesis involves effects of user characteristics and support on intention to use the system. There is a direct effect of user style on intention to use the system (0.48). General support (from friends, family and community) also directly affects intention to use (0.30). The other user characteristics indirectly affect intention to use the system, but through other constructs. Results also show several indirect effects from other constructs on intention to use. The highest indirect effects are from ease of use (0.277), general support (0.244) and access (0.1584). Several constructs indicated both direct and indirect effects on intention to use the system. These constructs are ease of use, general support, skills, Media2, access, school support, teacher support and Media1.

Results show that the fourth, fifth and sixth hypotheses are strongly supported. With regard to direct effect on intention to use, structural coefficients indicated that both perceived ease of use (0.47) and usefulness (0.49) produced significant paths to intention to use e-learning. The strongest effect is observed with regard to perception of easiness and system usefulness (0.63).

\subsection{The factors of gender, type of school, grade level and location}

Table 6 shows the F-value and level of significance when performing the one-way analysis of variance (ANOVA) to test differences with regard to the 13 constructs. The analysis is performed with regard to student gender, grade level, type of school and school location. The table also shows the means for each of the group categories.

Social media 1 use (Instagram, Keek and Twitter) is significantly affected by gender, type of school and school location, but not by grade level. Social media 2 use (Facebook and YouTube) is different across type of school and location of school only. 
Table 6 One-way ANOVA (F-value and significance and group means)

\begin{tabular}{|c|c|c|c|c|}
\hline Constructs & Gender & Grade level & Type of school & School location \\
\hline \multirow[t]{4}{*}{ Media 1} & $160.310(0.001)$ & $0.773(0.509)$ & $198.154(0.001)$ & $22.025(0.001)$ \\
\hline & Male (3.003) & Grade 10 (2.817) & Public (2.586) & $\mathrm{AD}(2.886)$ \\
\hline & Female (2.642) & Grade $11(2.800)$ & Private (2.991) & AA (2.709) \\
\hline & - & Grade 12 (2.833) & - & GH (2.829) \\
\hline \multirow[t]{4}{*}{ Media 2} & $2.219(0.109)$ & $6.696(0.001)$ & $276.923(0.001)$ & $41.159(0.001)$ \\
\hline & Male (1.729) & Grade $10(1.723)$ & Public (1.938) & $\mathrm{AD}(1.614)$ \\
\hline & Female (1.693) & Grade 11 (1.747) & Private (1.527) & AA (1.786) \\
\hline & - & Grade 12 (1.642) & - & GH (1.866) \\
\hline \multirow[t]{4}{*}{ Skill } & $103.017(0.001)$ & $0.249(0.862)$ & $146.179(0.001$ & $82.230(0.001)$ \\
\hline & Male (2.705) & Grade $10(2.820)$ & Public (2.674) & $\mathrm{AD}(2.927)$ \\
\hline & Female (2.919) & Grade $11(2.811)$ & Private (2.931) & AA $(2.740)$ \\
\hline & & Grade 12 (2.823) & & GH (2.600) \\
\hline \multirow[t]{4}{*}{ Performance } & $12.449(0.001)$ & $3.666(0.012)$ & $2.579(0.076)$ & $0.445(0.714$ \\
\hline & Male (2.729) & Grade 10 (2.793) & Public (2.784) & $\mathrm{AD}(2.761)$ \\
\hline & Female (2.798) & Grade 11 (2.749) & Private (2.752) & AA (2.776) \\
\hline & - & Grade $12(2.744)$ & - & GH (2.764) \\
\hline \multirow[t]{4}{*}{ Efficacy } & $0.848(0.428)$ & $3.189(0.023)$ & $20.880(0.001)$ & $2.432(0.063)$ \\
\hline & Male (3.248) & Grade $10(3.280)$ & Public (3.319) & $\mathrm{AD}(3.240)$ \\
\hline & Female (3.269) & Grade 11 (3.262) & Private (3.212) & AA (3.287) \\
\hline & & Grade 12 (3.217) & & GH (3.254) \\
\hline \multirow[t]{4}{*}{ Access } & $68.66(0.001)$ & $1.090(0.352)$ & $12.223(0.001)$ & $38.295(0.001)$ \\
\hline & Male (3.612) & Grade $10(3.741)$ & Public (3.674) & $\mathrm{AD}(3.814)$ \\
\hline & Female (3.827) & Grade $11(3.720)$ & Private (3.766) & AA (3.666) \\
\hline & - & Grade 12 (3.699) & - & GH (3.527) \\
\hline \multirow[t]{4}{*}{ Easiness } & $41.446(0.001)$ & $6.109(0.001)$ & $0.816(0.442)$ & $5.792(0.001)$ \\
\hline & Male (3.556) & Grade 10 (3.683) & Public (3.660) & $\mathrm{AD}(3.638)$ \\
\hline & Female (3.728) & Grade $11(3.650)$ & Private (3.639) & AA (3.624) \\
\hline & & Grade $12(3.580)$ & - & GH (3.569) \\
\hline \multirow[t]{4}{*}{ General support } & $16.227(0.001)$ & $13.412(0.001)$ & $21.402(0.001)$ & $0.886(0.448)$ \\
\hline & Male (3.229) & Grade 10 (3.343) & Public (3.353) & $\mathrm{AD}(3.277)$ \\
\hline & Female (3.333) & Grade 11 (3.276) & Private (3.232) & AA (3.301) \\
\hline & - & Grade 12 (3.195) & - & GH (3.257) \\
\hline \multirow[t]{4}{*}{ Usefulness } & $22.923(0.001)$ & $5.114(0.002)$ & $23.949(0.001)$ & $0.103(0.959)$ \\
\hline & Male (3.283) & Grade 10 (3.377) & Public (3.413) & $\mathrm{AD}(3.347)$ \\
\hline & Female (3.441) & Grade 11 (3.344) & Private (3.290) & AA (3.338) \\
\hline & - & Grade $12(3.290)$ & - & GH (3.332) \\
\hline \multirow[t]{4}{*}{ Style } & $31.887(0.001)$ & $0.132(0.941)$ & $1.158(0.314)$ & $6.418(0.001)$ \\
\hline & Male (3.245) & Grade 10 (3.306) & Public (3.304) & $\mathrm{AD}(3.317)$ \\
\hline & Female (3.362) & Grade 11 (3.310) & Private (3.312) & AA (3.319) \\
\hline & - & Grade 12 (3.298) & - & GH (3.216) \\
\hline \multirow[t]{2}{*}{ Intention to use } & $41.007(0.001)$ & $6.259(0.001)$ & $11.113(0.001)$ & $2.752(0.041)$ \\
\hline & Male (3.306) & Grade $10(3.431)$ & Public (3.434) & $\mathrm{AD}(3.394)$ \\
\hline
\end{tabular}


Table 6 (continued)

\begin{tabular}{lllll}
\hline Constructs & Gender & Grade level & Type of school & School location \\
\hline \multirow{5}{*}{ School support } & Female (3.461) & Grade 11 (3.375) & Private (3.352) & AA (3.399) \\
& - & Grade 12(3.354) & - & GH (3.318) \\
& $2.267(0.104)$ & $8.224(0.001)$ & $5.295(0.005)$ & $2.422(0.064)$ \\
& Male (3.116) & Grade 10 (3.182) & Public (3.175) & AD (3.265) \\
& Female (3.159) & Grade 11 (3.144) & Private (3.108) & AA (3.167) \\
& - & Grade 12 (3.053) & - & GH (3.081) \\
Teacher support & 3.082 (0.046) & 14.249 (0.001) & $70.224(0.001)$ & $18.550(0.001)$ \\
& Male (3.210) & Grade 10 (3.236) & Public (3.321) & AD (3.106) \\
& Female (3.159) & Grade 11 (3.199) & Private (3.075) & AA (3.265) \\
& & Grade 12 (3.068) & & GH (3.237) \\
\hline
\end{tabular}

With regard to student characteristics, student skills are significantly different depending on gender, school type and school location. However, self-efficacy differs only with regard to grade level and type of school. With regard to general support, results show that significantly different support is witnessed across gender, grade level and type of school. Teacher support is significantly different across gender, grade level, type of school and school location. School support is significantly different across grade level and type of school.

Intention to use is significantly different across all four category groups of gender, grade level, type of school and school location. Perception of how easy the intended system might be is different across gender, grade level and school location only. In addition, perception of system usefulness is significantly different across gender, grade level and type of school.

\section{Discussion}

The present study's results provide overall support for the application of an integrative model in order to explain and better understand students' intention to use e-learning systems if offered in high school in addition to the traditional classroom option. Testing the hypothesized structural model provided good overall fit to the data for the sample of Abu Dhabi students in grades 10,11 and 12. The model's validity further justifies the investigation of intention to use from a broad, integrative and system-wide perspective. The set of independent variables within the intention-to-use model accounted for $84.2 \%$ of variance. This result suggests that school planners and decision makers should consider intention to use online systems in an integrative model.

The paths representing direct and indirect effects of the construct predictors on intention to use provided statistical evidence of the validity of the 13 component predictors. More specifically, these results support the findings of previous research that showed significant links between intention to use e-learning, perception of easiness, perception of usefulness, and other factors such as user characteristics and support (Yang and Wang, 2014; Surjono 2014). 
Results show that both perceived usefulness and perceived ease of use had a significant direct effect on behavioural intention to use e-learning. The results are consistent with prior research using a sample of university students (Park, 2009). In Abu Dhabi, learning to use the Internet is normally considered easy and the benefits from learning through the Internet are already well known to students.

The results of estimating the proposed model demonstrate the importance of perceived ease of use and perceived usefulness in mediating the relationships between other factors and intention to use e-learning systems in high schools. The model indicated that beliefs in e-learning's usefulness and ease of use partially mediate the relationships linking use of social media, student performance in major subjects, student skills, efficacy, general support, teacher support, school support, access to the Internet and student style with intention to use of e-learning.

The results show that self-efficacy is an important determinant in perceived ease of use, consistent with other research results (Abbad et al., 2009; Venkatesh, \& Davis, 1996; Davis, 1989). Self-efficacy had a strong indirect effect upon students' intention to use e-learning, consistent with some prior studies (Doll et al., 1998).

The results show that comfort with technology supports intention to use online courses. One implication for schools is that they should work on motivating students to learn about technology. Educators would do well to prepare students for the technological demands of an online course through either prerequisites or direct training. Motivation to engage with and learn technological tools could easily be included as a prerequisite. Other research has also stressed that students who enrol in online courses must be prepared and motivated to engage with the tools needed for successful learning experiences (Rodriguez et al., 2008).

Support from various sources (including the school, teachers and the general community) was found to have an indirect effect on intention to use e-learning. This result indicates the importance of student support in influencing perceptions. This result is consistent with prior research involving university students (Abbad et al., 2009). The findings corroborate those of Smeets (2005) and Piccoli et al. (2001) that instructors' attitudes and competence related to e-learning have a significant effect on e-learners' satisfaction with or intention to use the system. In schools, teachers play key roles in students' learning processes in either traditional face-to-face teaching environments or remote learning environments (Sun and Tsai 2008). The results show that teacher support indirectly influences students' intention to use online learning tools through the teacher's personal style. Since not every instructor is interested in teaching online, the Abu Dhabi Education Council should recruit and select teachers carefully. Teacher attitudes toward using computer and network technology in delivering education will impact students' attitudes and style and will thereby affect their intention to use elearning resources.

General support from teachers, friends, family and the community support is the only construct that has both a direct influence on intention to use e-learning and an indirect influence through the two major constructs of easiness and usefulness of e-learning.

Meanwhile, the absence of a few of the constructs used in this study from other studies dealing with intention to use e-learning is worth noting. Factors such as use of social media and student performance in major school subjects had a significant effect 
on some of the constructs. Use of social media had an indirect effect on intention to use e-learning. In addition, the self-reported performance in major school subjects also had an indirect effect on user intention.

It seems that using social media such as Facebook and YouTube adds to students' skills and thereby enhances their efficacy level. This sense of efficacy in turn influences students' perception of the easiness and, hence, the usefulness of online subjects; and, as a major outcome of this research, both perceptions of easiness and usefulness have significant impact on students' intention to use the system in the future if it is offered. The other three social media resources of Twitter, Keek and Instagram directly influenced students' sense of efficacy, which in turn affects both easiness and usefulness. This result is in line with those research studies that call for the use of social media resources in schools (Koohang et al., 2009; De-Marcos et al., 2014).

One interesting result of the study is that both using social media and student performance in major school subjects play an important role in affecting attitudes toward use of e-learning. Both of these may be considered intrinsic motivational factors that could help students to self-regulate their motivation for e-learning. In Abu Dhabi, students are encouraged to use IT in class and at home to keep up with the social changes caused by IT. Students may want to adopt e-learning because they think that e-learning experience will be beneficial for their future job preparation.

Home access as an organizational factor was a dominant exogenous construct affecting student style directly and indirectly affecting user intention. This result is in contrast to other studies that did not see a dominant role of access to the Internet in influencing intention to use e-learning (Park, 2009). In Abu Dhabi, most homes have a developed IT infrastructure and most students have high-speed Internet at home. However, the cost of installing those services is relatively high, and as a result some students do not enjoy convenient access to rapid wi-fi infrastructure.

Previous studies did not test whether student performance in the school is a contributing factor to intention to use e-learning options. The current study provided a significant path from self-reported student performance to student skills (0.37). As a result, student performance showed an indirect effect on efficacy, ease of use, usefulness and intention to use e-learning.

In general, Abu Dhabi high-school students showed relatively strong abilities in dealing with education technology tools. Most variables related to student skills found strong knowhow on common computer-based technology activities. Most of the variables related to school support, teacher support, general support and home access scored relatively high scores (almost all above 3.0). With regard to social media, only YouTube got a high score. With regard to self-efficacy, perceptions of easiness, usefulness and intention to use e-learning, all variables received high marks. With regard to student style, students showed a strong tendency to be open to new ideas. They expressed a favourable view of learning in groups and stressed the importance of face-to-face interaction with teachers and students.

For the ADEC, if a limited level of technology skills jeopardizes attainment of positive learning experiences, students could be referred to appropriate resources to gain the essential technology skills before they enrol for an online course. 


\section{Conclusions, implications and limitations}

Developing education systems like Abu Dhabi's that are in the infancy stage of elearning adoption cannot afford to fail in e-learning implementation. Hence, it is essential to take cognizance of the users (students) as the major factor in any technology-enhanced learning environment, and to consider a wide range of factors relating to the all key players - students, teachers and institutions - in the implementation of e-learning.

This study has proposed and tested alternative models that seek to explain highschool students' intention to use an e-learning system, either as a supplementary learning tool within a traditional class or as a stand-alone distance education method. The models integrated determinants from previous research. Structural equation modelling provided better support for a model that hypothesized strong effects of perception of system ease and usefulness, with various other determinants playing mediating roles.

This study has implications for policy decisions in the area of ICT use in education, especially for systems similar to that of Abu Dhabi. The empirical analysis produced here could provide insights into the country-specific factors that facilitate optimum utilization of e-learning resources by students. This will enable government authorities such as the ADEC and others interested in use of technology to ensure that the critical factors for acceptance of e-learning and intention to use it are addressed in the implementation process. Thus the study contributes to the fashioning of suitable pedagogical methods for e-learning content in developing countries.

The results of this study demonstrated that some constructs in the model had a direct and indirect effect on school students' behavioural intention to use e-learning. This finding has clear implications for the development and management of e-learning in schools. For example, school educators and leaders should make a concerted effort to boost students' e-learning self-efficacy. Both online and offline support should be provided to build up this self-efficacy.

Perceived usefulness and ease of use had a direct effect on students' intention to use e-learning. Overlooking these constructs could have detrimental effects on student attitudes toward taking high-school courses online. Thus school teachers who design these online resources should help students to gain a positive perception of them. The elearning resources developed must be user-friendly and user-oriented.

To the best of our knowledge, this study is the first one that samples high-school students and explores the effect of social media and student performance in addition to other variables considered in prior research.

\subsection{Implication for further research}

This study has investigated learners' expected intention to use e-learning initiatives in Abu Dhabi high schools. As a continuation of this research, one could explore how a system actually performs after the initiation and implementation of e-learning. Future research could also explore further reasons for learners' satisfaction or dissatisfaction. A study similar to this one could be conducted in different cycles of schools to measure learners' satisfaction. This would help school decisionmakers to analyse different methods of e-learning approaches and designs and to discover the best method. 
Understanding some of the factors that may influence high-school students' intention to use online courses permits designing and delivering these courses so as to maximize their online educational experiences. After implementation of online courses, measuring satisfaction with online courses is an important factor in assessing the perceived quality of such courses for the purpose of redesign and modification. Perceptions of quality may also determine whether students continue to use such courses.

Future research should also explore teachers' viewpoints and their attitudes toward this educational innovation and should survey teachers as to the strengths and weaknesses of these programs in order to identify potential improvements.

\subsection{Limitations}

E-learning is a new educational initiative in Abu Dhabi and is in its infancy. The ADEC has recently introduced the idea of using e-learning programs in its schools. The respondents in this study (students in grades 10 through 12) had minimal experience of e-learning systems and were thus novice users of e-learning programs. This lack of experience may be considered a limitation of the present study, but it could also be considered a strength, in that the study's purpose was to determine how best to approach such learners.

One limitation was that students were not given a demonstration of the intended elearning system to be used in Abu Dhabi schools. Offering a live demonstration an hands-on practice, along with a chance to ask questions, would have enabled students to become familiar with the e-learning system, consistent with studies that have tested technology acceptance models in a variety of applications (e.g. Davis, 1989). This demonstration and practice should be designed to provide students with an understanding of the e-learning system's capabilities and they should show how the major functions could be accessed and used. The demonstration could include reviewing the key features of the system, showing, for example, how students can access lecture materials in video, audio or text format, take chapter and unit tests through the system, read and post articles in forums, participate in online chat or group discussions and use e-mail to turn in assignments.

Open Access This article is distributed under the terms of the Creative Commons Attribution License which permits any use, distribution, and reproduction in any medium, provided the original author(s) and the source are credited.

\section{References}

Abbad, M., Morris, D., Al-Ayyoub, A., \& Abbad, J. (2009). Students' decisions to use an e-learning system: A structural equation modelling analysis. International Journal of Emerging Technologies in Learning, 4(4), 4-13.

Adewole-Odeshi, E. (2014). Attitude of Students Towards E-learning in South-West Nigerian Universities. In An Application of Technology Acceptance Model. Library Philosophy and Practice (e-journal) (Digital Commons at University of Nebraska - Lincoln).

Albirini, A. (2006). Teachers' attitudes toward information and communication technologies: The case of Syrian EFL teachers. Computers and Education, 47(4), 373-398.

Alexander, S., McKemzie, J., \& Geissinger, H. (1998). An evaluation of information technology projects for university learning. Available from http://www.dest.gov.au/archive/cutsd/publications/exsummary.html.

Antal, B. (2007). The Facebook Phenomenon. Retrieved 28 March 2012, from http:/www.seochat.com/c/a/ Search-Engine-News/The-Facebook-Phenomenon/. 
Arbaugh, J. (2000). Virtual classroom characteristics and student satisfaction with internet-based MBA courses. Journal of Management Education, 24(1), 32-54.

Arbaugh, J. (2002). Managing the on-line classroom: A study of technological and behavioural characteristics of web-based MBA courses. Journal of High Technology Management Research, 13, 203-223.

Arbaugh, J., \& Duray, R. (2002). Technological and structural characteristics, student learning and satisfaction with web-based courses: An exploratory study of two on-line MBA programs. Management Learning, 33(3), 331-347.

Back, D., Haberstroh, N., Sostmann, K., Schmid, G., Putzier, M., Perka, C., \& Hoff, E. (2014). High Efficacy and students' satisfaction after voluntary vs mandatory use of an e-learning programing traumatology and orthopaedics - A follow-up study. Journal of Surgical Education, 71(3), 353-359.

Barbeite, F., \& Weiss, E. (2004). Computer self-efficacy and anxiety scales for an Internet sample: Testing measurement equivalence of existing measures and development of new scales. Computers in Human Behaviour, 20, 1-15.

Baylor, A., \& Ritchie, D. (2002). What factors facilitate teacher skill, teacher morale, and perceived student learning in technology-using classrooms? Computers and Education, 39, 395-414.

Bender, D., Wood, B., \& Vredevoogd, J. (2004). Teaching time: Distance education versus classroom instruction. American Journal of Distance Education, 18(2), 103-114.

Bouhnik, D., \& Marcus, T. (2006). Interaction in distance-learning courses. Journal of the American Society for Information Science and Technology, 57(3), 299-305.

Beyth-Marom, R., Chajut, E., Roccas, S., \& Sagiv, L. (2003). Internet-assisted versus traditional distance learning environments: Factors affecting students' preferences. Computers \& Education, 41(1), 65-76.

Breen, R., Lindsay, R., Jenkins, A., \& Smith, P. (2001). The role of information and communications technologies in a university learning environment. Studies in Higher Education, 26(1), 95-114.

Brett, P., \& Nagra, J. (2005). An investigation into students' use of a computer-based social learning space: Lessons for facilitating collaborative approaches to learning. British Journal of Educational Technology, 36(2), 281-292.

Carmo, L., Gomes, A., Pereira, F., \& Mendes, J. (2006). In Proceedings of the 3rd E-Learning ConferenceComputer Science Education (CD-ROM). Coimbra: Portugal. Learning styles and problem solving strategies.

Cheung, W., \& Huang, W. (2005). Proposing a framework to assess Internet usage in university education: An empirical investigation from a student's perspective. British Journal of Educational Technology, 36(2), 237-253.

Cheurprakobkit, S., Hale, D. F., \& Olson, J. N. (2002). Technicians' perceptions about web-based courses: The University of Texas system experience. American Journal of Distance Education, 16(4), 245-258.

Chiu, C., Hsu, M., Sun, S., Lin, T., \& Sun, P. (2005). Usability, quality, value and e-learning continuance decisions. Computers and Education, 45, 399-416.

Chwelos, P., Benbasat, I., \& Dexter, A. S. (2001). Empirical test of an EDI adoption model. Information Systems Research, 12(3), 304-321.

Collis, B., Oscar, P., \& Pals, N. (2001). A model for predicting the educational use of information and communication technologies. Instructional Science, 29(2), 95-125.

Conrad, D. L. (2002). Engagement, excitement, anxiety, and fear: Learners' experiences of starting an online course. American Journal of Distance Education, 16(4), 205-226.

Davis, F. (1989). Perceived usefulness, perceived ease of use, and user acceptance of information technology. MIS Quarterly, 13(3), 319-340.

De-Marcos, L., Domínguez, A., Saenz-de-Navarrete, J., \& Pagés, C. (2014). An empirical study comparing gamification and social networking on e-learning. Computers \& Education, 75, 8291.

Dewiyanti, S., Brand-Gruwel, S., Jochems, W., \& Broers, N. J. (2007). Students' experiences with collaborative learning in asynchronous computer-supported collaborative learning environments. Computers in Human Behaviour, 23(1), 496-514.

Doll, Wj., \& Torkzadeh, G. (1998). Developing a multidimensional measure of system-use in an organizational context. Information \& Management, 33(4), 171-185.

El-Deghaidy, H., \& Nouby, A. (2008). Effectiveness of a blended e-learning cooperative approach in an Egyptian teacher education programme. Computers and Education, 51, 988-1006.

Erdogan, Y., Bayram, S., \& Deniz, L. (2008). Factors that influence academic achievement and attitudes in web based education. International Journal of Instruction, 1(1), 32-47.

Gomes, A., Santos, A., Carmo, L., \& Mendes, A. (2007). Presentation at the International Conference of Engineering Education (ICEE). Coimbra: Portugal. Learning styles in an e-learning tool. 
Govindasamy, T. (2002). Successful implementation of e-learning: Pedagogical considerations. The Internet and Higher Education, 4(3-4), 287-299.

Graf, S., \& Kinshuk, R. (2006). An approach for detecting learning styles in learning management systems. In R. Kinshuk, P. Koper, P. Kommers, D. Kirschner, G. Sampson, \& W. Didderen (Eds.), Proceedings of the International Conference on Advanced Learning Technologies (pp. 161-163). Alamitos, CA: IEEE Computer Science.

Hara, N. (2000). Student distress in a web-based distance education course. Information, Communication and Society, 3(4), 557-579.

Helmi, A. (2002). An analysis on impetus of online education. The Internet and Higher Education, 4(3), 243253.

Holley, D. (2002). Which room is the virtual seminar in please? Education and Training, 44(3), 112-121.

Hong, K. (2002). Relationships between students' and instructional variables with satisfaction and learning from a Web-based course. Internet and Higher Education, 5, 267-281.

Horzum, H., \& Cakir, O. (2012). Structural equation modelling in readiness, willingness and anxiety of secondary school students about the distance learning. Procedia-Social and Behavioral Sciences, 47, 369-375.

Hu, J., Hui, W., Clark, T., \& Tam, K. (2007). Technology-assisted learning and learning style: A longitudinal field experiment. IEEE Transactions on Systems, Man, and Cybernetics-Part A: Systems and Humans, 37(6), 1099-1112.

Hung, M., Chou, C., Chen, C., \& Own, X. (2010). Learner readiness for online learning: Scale development and student perceptions. Computers and Education, 55, 1080-1090.

Jonsson, B. (2005). A case study of successful e-learning: A web-based distance course in medical physics held for school teachers of the upper secondary level. Medical Engineering \& Physics, 27, (2005) 571-581.

Joo, Y., Bong, M., \& Choi, H. (2000). Self-efficacy for self-regulated learning, academic self-efficacy, and Internet self-efficacy in Web-based instruction. Educational Technology Research and Development, 48, $5-17$.

Kanuka, H., \& Nocente, N. (2003). Exploring the effects of personality type on perceived satisfaction with web-based learning in continuing professional development. Decision Education, 24(2), 227-245.

Keller, C., \& Cernerud, L. (2002). Students' perception of e-learning in university education. Journal of Educational Media, 27(1-2), 55-65.

Khan, B. H. (2001). A framework for webbased learning. Engelwood Cliffs, NJ: Educational Technology Publications.

Kiili, K. (2005). Digital game-based learning: towards an experiential gaming model. Internet and Higher Education, 8(1), 13-24.

Kim, K., Park, I., Ko, Y., Jung, S., \& Cha, M. (2010). A structural analysis of effect factors on academic achievement. In Proceedings of the World Conference on Educational Multimedia, Hypermedia and Telecommunications 2010 (pp. 2421-2424). Chesapeake, VA: AACE.

Koohang A, Riley L, Smith T, Schreurs J. (2009). E-Learning and Constructivism: From Theory to Application. Interdisciplinary Journal of e-Learning and Learning Objects, 5, 91-109.

Koufaris, M. (2002). Applying the technology acceptance model and Xow theory to online consumer behavior. Information Systems Research, 13(2), 205-223.

Lederer, A., Maupin, D., Sena, M., \& Zhuang, Y. (2000). The technology acceptance model and the World Wide Web. Decision Support Systems, 29(3), 269-282.

Lee, J., \& Lee, W. (2008). The relationship of e-learners' self-regulatory efficacy and perception of e-learning environment quality. Computers in Human Behavior, 24, 32-47.

Liao, H., \& Lu, H. (2008). The role of experience and innovation characteristics in the adoption and continued use of e-learning websites. Computers and Education, 51, 1405-1416.

Liaw, S. (2004). Investigating students' perceived satisfaction, behavioural intention, and effectiveness of e-learning: A case study of the Blackboard system. Computers and Education, 51(2008), 864-873.

Liaw, S. (2007). Computers and the Internet as a job assisted tool: Based on the three-tier use model approach. Computers in Human Behaviour, 23, 399-414.

Liaw, S., \& Huang, H. (2003). An investigation of user attitudes toward search engines as an information retrieval tool. Computers in Human Behaviour, 19, 751-765.

Liaw, S., \& Huang, H. (2007). Developing a Collaborative e-Learning System Based on Users' Perceptions. Springer-Verlag Berlin Heidelberg:, 751-759.

Liaw, S., Huang, H., \& Chen, G. D. (2007). Surveying instructor and learner attitudes toward e-learning. Computers and Education, 49, 1066-1080. 
Lim, H., \& Lee, S. (2007). Validating e-learning factors affecting training effectiveness. International Journal of Information Management, 27, 22-35.

Mahdizadeh, H., Biemans, H., \& Mulder, M. (2008). Determining factors of the use of e-learning environments by university teachers. Computers and Education, 51, 142-154.

Manochehr, N. (2006). The influence of learning styles of learners in e-learning environments: An empirical study (Information Systems Department 18th ed., pp. 10-14). Qatar University: CHEER.

Marriott, N., Marriott, P., \& Selwyn, N. (2004). Accounting undergraduates' changing use of ICT and their views on using the Internet in higher education: A research note. Accounting Education, 13 (supplement 1), 117-130.

Mason, C. (2006). Edge of Chaos - eLearning. Retrieved 28 March 2012, from http://scope.bccampus.ca/ $\mathrm{mod} /$ forum/discuss.php?d=197.

McGill, T., Klobas, J., \& Klobas, J. (2009).

Mc Veigh, H. (2008). Factors influencing the utilization of e-learning in post-registration nursing students. Nurse Education Today, 29(1), 91-9.

Moore, M. (1989). Three types of interactions. The American Journal of Distance Education, 3(2), 1-7.

Ong, C., \& Lai, J. (2006). Gender differences in perceptions and relationships among dominants of e-learning acceptance. Computers in Human Behavior, 22(5), 816-829.

Oye, N. A., Iahad, N., Madar, M. J., \& Rahim, N. (2012). The impact of e-learning on students' performance in tertiary institutions. International Journal of Computer Networks and Wireless Communications, 2(2)), $121-130$.

Papp, R. (2000). Critical success factors for distance learning. Paper presented at the Americas Conference on Information Systems. CA, USA: Long Beach.

Park, S. (2009). An analysis of the technology acceptance model in understanding university students' behavioural intention to use e-learning. Educational Technology and Society, 12(3), 150-162.

Passerini, K., \& Granger, M. (2000). A developmental model for distance learning using the Internet. Computers and Education, 34, 1-15.

Peng, H., Tsai, C., \& Wu, Y. (2006). University students' self-efficacy and their attitudes toward the Internet: The role of students' perceptions of the Internet. Educational Studies, 32, 73-86.

Petrova, K. (2007). Mobile learning as a mobile business application. International Journal of Innovation and Learning, 4(1), 1-13.

Piccoli, G., Ahmad, R., \& Ives, B. (2001). Web-based virtual learning environments: a research framework and a preliminary assessment of effectiveness in basic IT skill training. MIS Quarterly, 25(4), 401-426.

Pituch, A., \& Lee, Y. (2006). The influence of system characteristics on e-learning use. Computers and Education, 47, 222-244.

Rai, A., Lang, S., \& Welker, R. (2002). Assessing the validity of IS success models: An empirical test and theoretical analysis. Information Systems Research, 13(1), 50-69.

Roca, J., \& Chiu, C. (2006). Understanding e-learning continuance intention: An extension of the Technology Acceptance Model. International Journal of Human- Computer Studies, 64, 683-696.

Rodriguez, M., Ooms, A., \& Montañez, M. (2008). Students' perceptions of online-learning quality given comfort, motivation, satisfaction, and experience. Journal of Interactive Online Learning, 7(2), 105-125.

Rong, W., \& Min, Y. (2005) The effects of learning style and flow experience on the effectiveness of elearning. In Fifth IEEE International Conference on Advanced Learning Technologies, 802-805.

Rosen, D., \& Nelson, C. (2008). Web 2.0: A new generation of learners and education. Computers in the Schools, 25, 211-225.

Rosenberg, M. (2001), E-Learning: Strategies for Delivering Knowledge in the Digital Age, McGraw-Hill, New York.

Ruth, S. (2006). E-learning: A financial and strategic perspective. Educause Quarterly, 29(1), 22-30.

Segars, A., \& Grover, V. (1993). Re-examining perceived ease of use and usefulness: A conWrmatory factor analysis. MIS Quarterly, 17(4 (December), 517-525.

Selim, H. (2007). Critical success factors for e-learning acceptance: Confirmatory factor models. Computers and Education, 49, 396-413.

Selwyn, N. (2007). The use of computer technology in university teaching and learning: A critical perspective. Journal of Computer Assisted Learning, 23(2), 83-94.

Shen, C., \& Chuang, H. (2010). Exploring users' attitudes and intentions toward the interactive whiteboard technology environment. International Review on Computers and Software, 5(2), 200-208.

Silius, K., Miilumäki, T., Huhtamäki, J., Tebest, T., Meriläinen, J., \& Pohjolainen, S. (2010). Students' motivations for social media enhanced studying and learning. Knowledge Management \& E-Learning: An International Journal, 2, 51-67. 
Smeets, E. (2005). Does ICT contribute to powerful learning environments in primary education? Computers \& Education, 44, 343-355

Smith, D., \& Hardaker, G. (2000). E-Learning innovation through the implementation of an Internet-supported learning environment. Educational Technology and Society, 3, 1-16.

Soon, K., Sook, K., Jung, C., \& Im, K. (2000). The effects of Internet-based distance learning in nursing. Computers in Nursing, 18(1), 19-25.

Soong, B., Chan, H., Chua, B., \& Loh, K. (2001). Critical success factors for on-line course resources. Computers and Education, 36(2), 101-120.

Stansfield, M., McLellan, E., \& Connolly, T. (2004). Enhancing student performance in online learning and traditional face-to-face class delivery. Journal of Information Technology Education, 3, 173-188.

Sun, P., \& Tsai, R. (2008). What drives a successful e-learning? An empirical investigation of the critical factors influencing learner satisfaction. Computers and Education, 50, 1183-1202.

Surjono, H. (2014). The evaluation of a model based adaptive e-learning system. International Journal of Information and Education Technology, 4(1), 89-92.

Surry, D., Ensminger, D., \& Haab, M. (2005). A model for integrating instructional technology into higher education. British Journal of Educational Technology, 36(2), 327-329.

Thompson, L., Meriac, J., \& Cope, J. (2002). Motivating online performance: The influences of goal setting and Internet self-efficacy. Social Science Computer Review, 20, 149-160.

Thurmond, V., Wambach, K., \& Connors, H. (2002). Evaluation of student satisfaction: Determining the impact of a web-based environment by controlling for student characteristics. American Journal of Distance Education, 16(3), 169-189.

Tsai, C., \& Lin, C. (2004). Taiwanese adolescents' perceptions and attitudes regarding the Internet: exploring gender differences. Adolescence, 39, 725-734.

Ullrich, C., Shen, R., \& Gillet, D. (2010). Not yet ready for everyone: An experience report about a personal learning environment for language learning. In X. Luo, M. Spaniol, L. Wang, Q. Li, W. Nejdl, \& W. Zhang (Eds.), Advances in Web-Based Learning - ICWL 2010 (pp. 269-278).

Venkatesh, V., \& Davis, F. (1996). A model of the antecedents of perceived ease of use: Development and test. Decision Sciences, 27(3), 451-481.

Venkatesh, V., \& Davis, F. D. (2000). A theoretical extension of the technology acceptance model: Four longitudinal Weld studies. Management Science, 46(2), 186-204.

Venkatesh, V., Morris, M., Davis, G., \& Davis, F. (2003). User acceptance of information technology: Towards a unified view. MIS Quarterly, 27(3), 425-478.

Volery, T., \& Lord, D. (2000). Critical success factors in online education. International Journal of Educational Management, 14(5), 216-223.

Vuorela, M., \& Nummenmaa, L. (2004a). Experienced emotions, emotion regulation and student activity in a web-based learning environment. European Journal of Psychology of Education, 14(4), 423-436.

Vuorela, M., \& Nummenmaa, L. (2004b). How undergraduate students meet a new learning environment? Computers in Human Behavior, 20, 763-777.

Wang, A., \& Newlin, M. (2002). Predictors of web-student performance: The role of self-efficacy and reasons for taking an on-line class. Computers in Human Behaviour, 18, 151-163.

Wang, Q. (2008). A generic model for guiding the integration of ICT into teaching and learning. Innovations in Education and Teaching International, 45(4), 411-419.

Wu, J., \& Tennyson, R. (2008). Analysis of e-learning innovation and core capability using a hypercube model. Computers in Human Behaviour, 24, 1851-1866.

Yang, F., \& Wang, S. (2014). Students' perception toward personal information and privacy disclosure in e-learning. TOJET: The Turkish Online Journal of Educational Technology., 13(1), 207-216.

Yi, M., \& Hwang, Y. (2003). Predicting the use of web-based information systems: Self-efficacy, enjoyment, learning goal orientation, and the technology acceptance model. International Journal of HumanComputer Studies, 59, 431-449.

Yuen, A., \& Ma, W. (2008). Exploring teacher acceptance of e-learning technology. Asia-Pacific Journal of Teacher Education, 36(3), 229-243. 